\title{
UPAYA MENINGKATKAN KEMAMPUAN BERFIKIR KREATIF PESERTA DIDIK DENGAN PEMBELAJARAN KONTEKSTUAL HUMANISTIK
}

\author{
Simon Maruli Panjaitan \\ Universitas HKBP Nommensen Medan \\ simon.panjaitan@yahoo.co.id
}

\begin{abstract}
This study aims to determine the increase in students' creative thinking on the Social Arithmetic Material at SMP Yapim Medan. This type of research is classroom action research with 26 research subjects. The instruments used were tests and observations. The average value of teacher observation in cycle I was $75 \%$ and increased in cycle II to $84.38 \%$ in the good category, while the average value of student activity observation in the first cycle was $62.25 \%$ in the good category, where as in cycle II it was $68.63 \%$ in the good category. The average of creative thinking of students in the initial test obtained $44.32 \%$ increased to $69.92 \%$ in the first cycle and $78.04 \%$ in the second cycle. Because the activities of students increased, teacher observation increased and the ability of creative thinking of students also increased from cycle I to cycle II, it can be concluded that the students' creative thinking ability with humanistic contextual learningincreases.
\end{abstract}

Keywords: Creative thinking ability, Humanistic contextual learning

\section{Abstrak}

Penelitian ini bertujuan untuk mengetahui peningkatan berfikir kreatif peserta didik pada materi Aritmatika Sosial SMP Yapim Medan. Jenis penelitian adalah penelitian tindakan kelas dengan subjek penelitian berjumlah 26 orang. Instrumen yang digunakan adalah tes dan observasi. Nilai rata-rata observasi guru di siklus I sebesar $75 \%$ dan meningkat di siklus II menjadi 84,38\% kategori baik, sedangkan nilai rata-rata observasi aktifitas peserta didik pada siklus I 62,25 \% dengan kategori baik, sedangkan pada Siklus II sebesar 68,63\% dengan kategori baik. Rata-rata berfikir kreatif peserta didik pada tes awal diperoleh $44.32 \%$ meningkat menjadi $69.92 \%$ di siklus I dan $78.04 \%$ di siklus II.. Karena aktifitas peserta didik meningkat, observasi guru meningkat dan kemampuan berfikir kreatif peserta didik juga meningkat dari siklus I ke siklus II maka dapat disimpulkan kemampuan berfikir kreatif peserta didik dengan pembelajaran kontekstual humanistik meningkat.

Kata Kunci : Kemampuan berfikir kreatif, Pembelajaran kontekstual Humanistik 


\section{Pendahuluan}

Mutu pendidikan menjadi salah satu masalah nasional yang dihadapi saat ini. Faktanya, banyak peserta didik mampu menyajikan tingkat hafalan yang baik terhadap materi ajar yang diterimanya, namun pada kenyataannya mereka tidak memahami manfaatnya dalam kehidupan sehari-hari. Selama ini dalam pelaksanaan pembelajaran di sekolah masih banyak guru yang mendesain peserta didik untuk menghafal seperangkat fakta yang diberikan oleh guru, seolah-olah guru dianggap sebagai sumber informasi, sehingga komunikasi hanya berlangsung satu arah saja yaitu hanya dari guru ke peserta didik. Pada akhirnya pembelajaran cenderung monoton, kaku, dan tidak ada kegairahan serta pembelajaran seperti inilah yang disebut dengan pembelajaran berorientasi pada guru. Akibatnya, pendidikan di Indonesia tidak berkembang dan menghasilkan Sumber Daya Manusia yang rendah. Matematika merupakan pelajaran yang dapat menumbuh kembangkan berbagai kemampuan peserta didik. Kemampuan peserta didik untuk menemukan struktur dan konsep materi, sehingga dengan kemampuan tersebut peserta didik mampu berpikir matematik, kreatif dan meningkatkan kemampuan lainnya. Kemampuan berpikir kreatif sangatlah penting karena pada era globalisasi ini,. Untuk itu manusia dituntut memiliki kemampuan dalam memperoleh, memilih, mengelola, menindaklanjuti informasi tersebut untuk menyelesaikan masalah yang terjadi dalam kehidupan yang dinamis, sarat tantangan, dan penuh kompetisi. Hal tersebut menuntut kita memiliki kemampuan berpikir dan kreatif dalam menghadapi permasalahan dan menyelesaikannya.

Berpikir kreatif menurut Munandar (1999: 48) adalah kemampuan menemukan banyak kemungkinan jawaban terhadap suatu masalah, dimana penekanannya adalah pada kuantitas, ketepatgunaan dan keragaman jawaban berdasarkan data atau informasi yang tersedia. Aspek berpikir kreatif menurut Evans (1991: 51) dan Guilford (1967: 138) adalah fluency (kelancaran), flexibility (keluwesan), originality (keaslian), dan elaboration (penguraian). Ciri-ciri orang yang memiliki kemampuan berpikir kreatif adalah terbuka terhadap pengalaman baru, luwes dalam berpikir, percaya pada gagasan sendiri, dan mandiri. Sayangnya, dalam masyarakat sekarang, orang berpikir bahwa kemampuan berpikir kreatif bukan sebuah kebiasaan berpikir yang seharusnya ditanamkan sejak usia dini. Salah satu cara mengembangkan kemampuan berpikir kreatif melalui kegiatan pembelajaran matematika. Hal tersebut dikarenakan tujuan pembelajaran matematika di sekolah menurut Depdiknas (2003: 3) adalah (1) melatih cara berpikir dan bernalar dalam menarik kesimpulan; (2) mengembangkan aktivitas kreatif yang melibatkan 
imajinasi, intuisi, dan penemuan dengan mengembangkan pemikiran divergen, orisinil, rasa ingin tahu, membuat prediksi dan dugaan, serta mencoba-coba; (3) mengembangkan kemampuan memecahkan masalah; dan (4) mengembangkan kemampuan menyampaikan informasi dan mengomunikasikan gagasan. Kemampuan berpikir kreatif yang rendah dialami peserta didik merupakan hal yang wajar jika dilihat dari aktivitas pembelajaran di kelas yang selama ini dilakukan hanya sebagai rutinitas belaka. Penyampain materi, contoh soal dan lagi-lagi latihan yang sifatnya rutin dan kurang melatih daya pikir peserta didik.

\subsection{Identifikasi Masalah}

Berdasarkan latar belakang yang telah dikemukakan tersebut, maka peneliti mengidentifikasi beberapa masalah, yaitu:

1. Pembelajaran cenderung monoton, kaku, dan tidak ada kegairahan serta pembelajaran itu disebut pembelajaran berorientasi pada guru.

2. Peserta didik mengalami kesulitan dalam mempelajari dan memahami pelajaran matematika

3. Rendahnya kemampuan berpikir kreatif matematika peserta didik.

\subsection{Batasan Masalah}

Dari masalah-masalah yang telah diidentifikasi, penelitian dibatasi pada pembelajaran matematika dengan Pembelajaran Kontekstual Humanistiksebagai upaya meningkatkan kemampuan kreatif matematis peserta didik dengan materi Aritmatika Sosial.

\subsection{Rumusan Masalah}

Berdasarkan latar belakang masalah, identifikasi dan pembatasan masalah, maka rumusan masalah dari penelitian ini adalah apakah dengan penerapan Pembelajaran Kontekstual Humanistik dapat meningkatkan kemampuan berpikir kreatif matematis peserta didik kelas VII SMP Yapim Medan?

\subsection{Tujuan Penelitian}

Secara umum penelitian ini bertujuan untuk mengetahui apakah penerapan Pembelajaran Kontekstual Humanistik dapat meningkatkan kemampuan berpikir kreatif matematis peserta didik kelas VII SMP Yapim Medan.

\subsection{Defenisi Operasional}

1. Berpikir kreatif menurut Munandar (1999: 48) adalah kemampuan menemukan banyak kemungkinan jawaban terhadap suatu masalah, dimana penekenannya adalah pada kuantitas, ketepatgunaan dan keragaman jawaban berdasarkan data atau informasi yang tersedia. 
2. Teori Humanistik adalah teori belajar yang memanusiakan manusia. Pembelajaran dipusatkan pada pribadi seseorang

3. Pembelajaran dengan pendekatan kontekstual mengupayakan agar suasana pembelajaran menjadi menyenangkan, sehingga adanya perubahan tingkah laku dan kompetensi yang dicapai oleh peserta didik.

\section{Metode Penelitian}

\subsection{Lokasi dan Waktu Penelitian}

\section{Lokasi Penelitian}

Lokasi penelitian ini dilaksanakan di SMP Swasta Yapim Medan.

\section{Waktu Penelitian}

Waktu penelitian dilaksanakan pada semester ganjil T.A. 2019/2020.

\subsection{Subjek dan Objek Penelitian}

\section{Subjek}

Subjek pada penelitian ini adalah seluruh peserta didik semester I kelas VII

pada T.A. 2019/2020.

\section{Objek}

Objek dalam penelitian ini adalah kemampuan berfikir kreatif peserta didik.

\subsection{Jenis dan Desain Penelitian}

Jenis penelitian ini adalah penelitian tindakan kelas (classroom action research) yaitu penelitian tindakan (action research). Menurut Mahmud (2011: 199) Penelitian Tindakan Kelas (PTK) merupakan "suatu bentuk penelitian yang bersifat reflektif dengan melakukan tindakan-tindakan tertentu untuk memperbaiki atau meningkatkan praktik-praktik pembelajaran di kelas lebih profesional

\subsection{Prosedur Penelitian}

Sesuai dengan jenis penelitian ini yaitu penelitian tindakan kelas, maka penelitian ini memiliki beberapa tahap yang merupakan suatu siklus. Tiap siklus dilaksanakan sesuai dengan perubahan yang akan dicapai. Untuk mengatasi permasalahan yang ada peneliti melakukan wawancara dengan guru matematika yang ada di sekolah tempat peneliti melakukan penelitian. Wawancara ini bertujuan untuk mengetahui kemampuan peserta didik dan kesulitan peserta didik dalam pemecahan masalah. Hasil wawancara ini kemudian digunakan sebagai dasar untuk 
membuat rencana tindakan. Penelitian tindakan kelas dilakukan dalam bentuk siklus berulang yang didalam siklus terdapat empat tahapan utama kegiatan, yaitu: (1) Permasalahan, (2) Perencanaan, (3) Pelaksanaan, (4) obsevasi, (5) Refleksi.

\subsection{Alat Pengumpulan Data}

Dalam penelitian ini digunakan alat pengumpulan data, yaitu tes kemampuan berfikir kreatif dan observasi.

\section{Tes Kemampuan Berfikir Kreatif}

Menurut Arikunto (2007: 53) menyatakan bahwa: "Tes merupakan alat atau prosedur yang digunakan untuk mengetahui atau mengukur sesuatu dalam suasana, dengan cara-cara dan aturan yang sudah ditentukan". Tes yang diberikan berbentuk tes uraian dimana tes yang digunakan dalam penelitian ini adalah tes diagnostik (sebelum pemberian tindakan). Tes digunakan untuk mengetahui tingkat kemampuan berfikir kreatif matematika sebelum dan setelah pembelajaran. Tes yang digunakan disusun sesuai dengan kurikulum dan tujuan pengajaran yang telah ditentukan. Dari hasil tes ini dapat dilihat tingkat kemampuan berfikir kreatif matematika pada siklus I dan siklus II.

\section{Observasi}

Lembar observasi digunakan untuk mengobservasi atau menilai suatu pembelajaran yang sedang berlangsung. Observasi yang dilakukan untuk mengetahui kenyataan yang terjadi didalam kelas. Observasi dilakukan pada saat pembelajaran berlangsung. Dalam hal ini guru bidang studi matematika bertugas untuk mengobservasi peserta didik selama kegiatan belajar mengajar dilakukan. Guru juga diobservasi untuk melihat kemampuan guru dalam pelaksanaan pembelajaran.

\subsection{Teknik Analisis Data}

Analisis data dalam penelitian ini dilakukan dalam beberapa tahap yaitu:

\section{Reduksi Data}

Proses reduksi data dilakukan dengan menyeleksi, menyederhanakan dan mentransformasikan data yang telah disajikan dalam bentuk transkrip catatan lapangan. Kegiatan reduksi data ini bertujuan untuk melihat kesalahan jawaban peserta didik dalam menyelesaikan soal-soal dan tindakan apa yang dapat dilakukan untuk memperbaiki kesalahan itu.

\section{Paparan Data}


a) Menganalisis Hasil Observasi

1) Hasil Observasi aktivitas belajar peserta didik

Tabel 2.1 Kriteria Penilaian Observasi Peserta Didik

\begin{tabular}{|c|l|}
\hline Penilaian & \multicolumn{1}{|c|}{ Kriteria } \\
\hline $0 \%<$ PAPD $\leq 60 \%$ & kurang aktif \\
$60 \% \leq$ PAPD $<70 \%$ & cukup aktif \\
$70 \% \leq$ PAPD $<85 \%$ & aktif \\
PAPD $\geq 85 \%$ & sangat aktif \\
\hline
\end{tabular}

2) Hasil Observasi Aktivitas Guru

Tabel 2.2 Kriteria penilaian Observasi Guru

\begin{tabular}{|c|l|}
\hline Penilaian & \multicolumn{1}{|c|}{ Kriteria } \\
\hline $0 \%-25 \%$ & Sangat Buruk \\
$26 \%-50 \%$ & Kurang Baik \\
$51 \%-75 \%$ & Baik \\
$76 \%-100 \%$ & Sangat Baik \\
\hline
\end{tabular}

b) Menghitung tingkat penguasaan peserta didik

Tingkat penguasaan peserta didik dapat ditentukan dengan memakai

hitungan Persentase Penguasaan Peserta Didik (PPPD)

$$
P P P D=\frac{\text { Skor yang diperoleh peserta didik }}{\text { Skor maksimal }} \times 100 \%
$$

Kriteria penguasaan peserta didik adalah sebagai berikut:

Tabel 2.3 Kriteria Tingkat Penguasaan Peserta Didik

\begin{tabular}{|c|l|}
\hline Tingkat Penguasaan & \multicolumn{1}{c|}{ Kriteria } \\
\hline $90 \%-100 \%$ & Kemampuan sangat tinggi \\
$80 \%-89 \%$ & Kemampuan tinggi \\
$70 \%-79 \%$ & Kemampuan sedang \\
$60 \%-69 \%$ & Kemampuan rendah \\
$0 \%-59 \%$ & Kemampuan sangat rendah \\
\hline
\end{tabular}

Dikatakan mencapai tingkat penguasaan peserta didik apabila mencapai kriteria paling sedikit sedang.

c) Untuk menentukan ketuntasan belajar peserta didik (individual) dapat dihitung dengan menggunakan persamaan seperti yang dikemukakan oleh Depdikbud (dalam Trianto, 2008: 171) yaitu:

$$
\mathrm{KB}=\frac{T}{T t} \times 100 \%
$$

Dimana : $\quad \mathrm{KB}=$ ketuntasan belajar

$$
\mathrm{T} \text { = jumlah skor yang diperoleh peserta didik }
$$




$$
\mathrm{Tt}=\text { jumlah skor total }
$$

Setiap peserta didik dikatakan tuntas belajarnya (ketuntasan individual) jika proporsi jawaban benar peserta didik $\geq 70 \%$.

d) Selanjutnya dapat juga diketahui apakah ketuntasan belajar secara klasikal telah tercapai, dilihat dari persentase peserta didik yang sudah tuntas dalam belajar yang dirumuskan seperti yang dikemukakan oleh Suryobroto (2007: 28) sebagai berikut:

$$
\mathrm{PKK}=\frac{\text { banyaknya } \text { peserta didik } y \text { ang } K B \geq 70 \%}{\text { banyak subjek penelitian }} \times 100 \%
$$

Keterangan :

PKK $=$ Persentase Ketuntasan Klasikal

\section{Simpulan Data/Indikator Keberhasilan}

Kemampuan kemampuan berfikir kreatif matematika peserta didik dikatakan meningkat jika:

a. Terdapat pertambahan rata-rata persentase kemampuan berfikir kreatif matematika peserta didik dari siklus I ke siklus II

b. Persentase aktivitas peserta didik minimal cukup aktif.

c. Persentase aktivitas peserta didik minimal baik.

Bila indikator keberhasilan diatas tercapai maka pembelajaran yang dilaksanakan peneliti dikatakan berhasil. Tetapi bila indikatornya belum tercapai maka pengajaran yang dilaksanakan peneliti belum berhasil.

\section{Hasil Penelitian Dan Pembahasan}

\subsection{Hasil}

\subsubsection{Kemampuan Awal}

Siklus I terdiri atas empat tahapan yaitu tahap perencanaan, tahap pelaksanaan, tahap pengamatan dan reflektif. Dari hasil pre-test terlihat jelas hanya 5 orang dari 26 siswa yang tuntas, berikut deskripsi tingkat kemampuan siswa pada tes awal di Tabel 3.1

Tabel 3.1 Deskripsi Tingkat Kemampuan Siswa pada Tes Awal

\begin{tabular}{|l|l|l|l|l|}
\hline Persentase & Tingkat & Banyak & Persentase & Rata - rata \\
\hline
\end{tabular}




\begin{tabular}{|c|c|c|c|c|}
\hline $\begin{array}{c}\text { Tingkat } \\
\text { Penguasaan }\end{array}$ & Kemampuan & Siswa & $\begin{array}{l}\text { Jumlah } \\
\text { Siswa }\end{array}$ & $\begin{array}{c}\text { Kemampuan } \\
\text { Berpikir } \\
\text { Kreatif }\end{array}$ \\
\hline $90 \%-100 \%$ & Sangat Tinggi & 0 orang & $0 \%$ & \multirow{5}{*}{$\begin{array}{c}44.32 \% \text { sangat } \\
\text { Rendah }\end{array}$} \\
\hline $80 \%-89 \%$ & Tinggi & 0 orang & $0 \%$ & \\
\hline $65 \%-79 \%$ & Sedang & 5 orang & $19 \%$ & \\
\hline $55 \%-64 \%$ & Rendah & 3 orang & $11 \%$ & \\
\hline $0 \%-54 \%$ & Sangat Rendah & 18 orang & $69 \%$ & \\
\hline
\end{tabular}

\subsubsection{Kesimpulan pada siklus 1}

Dari hasil tes kemampuan berpikir kreatif matematis pada siklus I diperoleh bahwa dari 26 orang siswa terdapat 14 orang atau 53,84\% siswa yang tes kemampuan berpikir kreatif matematis diatas nilai 70 atau sama dengan 70 . Dan 12 orang atau $46,153 \%$ siswa yang tes kemampuan berpikir kreatif matematis dibawah 70 . Skor tertinggi adalah 88 dan skor terendah adalah 40. Nilai rata-rata kelas adalah 69,923 dan secara klasikal ketuntasan belajar siswa adalah 53,84\%. Sementara untuk hasil observasi guru pada siklus 1,sudah baik tapi masih masih ada kekurangan seperti kemampuan mendefinisikan dan mengorganisasikan tugas belajar yang berhubungan dengan masalah dan kemampuan membantusiswa dalam merencanakan dan menyiapkan hasil masalah masih rendah.

\subsubsection{Kesimpulan siklus II}

Dari hasil tes kemampuan berpikir kreatif matematis siswa pada siklus II diperoleh bahwa dari 26 orang siswa terdapat 24 orang atau 92,307\% siswa yang tes kemampuan berpikir kreatif matematis $\geq 70$. Dan 2 orang atau 7,692\% siswa yang tes kemampuan berpikir kreatif matematis dibawah 70. Skor tertinggi adalah 92 dan skor terendah adalah 60. Nilai rata-rata kelas adalah 78,048 dan secara klasikal ketuntasan belajar siswa adalah 92,307\%. Sementara untuk hasil observasi guru pada siklus I dan II dalam kategori baik, terdapat peningkatan rata-rata di siklus I dan II.

\subsection{Pembahasan Penelitian}

Berdasarkan hasil penelitian dan analisis data yang telah dilakukan diperoleh temuan penelitian sebabagai berikut:

1. Di awal, peserta didik diberikan pre-test yang bertujuan untuk mengetahui letak kesulitan siswa dalam materi operasi hitung aljabar. Dari pre-test 
diperoleh bahwa terdapat 5 dari 26 peseta didik yang mendapat nilai $\geq 70$ atau terdapat peserta didik $80,8 \%$ yang belum tuntas. Dengan ketuntasan kemampuan berpikir kreatif matematis siswa secara individual 44,32 \% masih kategori sangat rendah dan pada saat siklus I diperoleh hasil bahwa terdapat 14 dari 26 siswa yang mendapat nilai $\geq 70$ atau terdapat siswa 46,153\% yang belum tuntas. Dengan ketuntasan berpikir kreatif matematis peserta didik secara individual 69,92\% sudah baik dan lagi dilanjutkan ke siklus II diperoleh hasil bahwa terdapat 24 dari 26 siswa yang mendapat nilai $\geq 70$ atau terdapat peserta didik 7,692\% yang belum tuntas dengan ketuntasan berpikir kreatif matematis peserta didik secara individual $75,04 \%$ maka ketuntasan secara individual tercapai.

2. Dari pre-test diperoleh ketuntasan kemampuan berpikir kreatif matematis peserta didik secara klasikal $11,538 \%$ yang masih sangat rendah dan pada siklus I diperoleh ketuntasan klasikal nya hanya 53,84\% belum mencapai ketuntasan belajar secara klasikal dan dilanjutkan ke siklus II dengan hasil ketuntasan klasikalnya mencapai 92,307\% maka kriteria klasikalnya sudah tercapai.

3. Berdasarkan observasi yang dilakukan terhadap guru oleh observer pada siklus I diperoleh bahwa kategori pelaksanaan pembelajaran baik dengan persentase 75\% dan pada siklus II adanya peningkatan bahwa kategori pelaksanaan pembelajaran baik dengan persentase $84,4 \%$.

4. Dari hasil pengamatan tehadap aktivitas belajar peserta didik dengan menggunakan pembelajaran Pembelajaran Kontekstual Humanistik terhadap kemampuan berpikir kreatif matematis peserta didik mengalami adanya peningkatan kegiatan aktivitas peserta didik. Pada siklus I diperoleh nilai persentase nya yaitu 62,25\% dengan kategori baik dan dilanjutkan ke siklus II diperoleh hasil persentase yaitu $68,63 \%$ dengan kategori peserta didik melakukan aktivitas dengan baik. Dengan demikian dapat disimpulkan bahwa Penerapan model pembelajaran Pembelajaran Kontekstual Humanistik dapat meningkatkan kemampuan berpikir kreatif matematis siswa SMP Swasta Yapim Medan.

\section{Kesimpulan dan Saran}

\subsection{Kesimpulan}

Penerapan pembelajaran Kontekstual Humanistik dapat meningkatkan kemampuan berpikir kreatif matematis siswa kelas VII- SMP Yapim Medan. 


\subsection{Saran}

Berdasarkan hasil dan kesimpulan dalam penelitian ini, maka penulis mempunyai beberapa saran antara lain:

1. Kepada guru matematika, dalam mengajarkan materi aritmatika sosial hendaknya guru menggunakan model pembelajaran Pembelajaran Kontekstual Humanistik sebagai salah satu alternatif untuk meningkatkan kemampuan berpikir kreatif matematis siswa.

2. Kepada peneliti yang berminat melakukan penelitian dengan objek yang sama diharapkan mampu mengelola kelas dengan baik dan mampu mengembangkan penelitian dengan mempersiapkan model pembelajaran Pembelajaran Kontekstual Humanistik.

\section{DAFTAR PUSTAKA}

Budiningsih. 2005. Tujuan Pembelajaran beraliran Humanistik. Bandung: PT. Refika

B.Uno, Hamzah. 2007. Model Pembelajaran Menciptakan Proses Belajar Mengajar yang Efektif dan Kreatif. Jakarta: Bumi Aksara

Chundari. 2012. Landasan Matematika. Yogyakarta: Teras

Dalyono. 2005.Pengertian Belajar. Jakarta Rineka Cipta

Hassoubah.2008. Mengasah Pikiran Kreatif Dan Kritis. Bandung: Nuansa.

Munandar, Utami. 1999. Mengembangkan Bakat dan Kreatifitas Anak Sekolah. Jakarta:Gramedia . 2009. Pengembangan Kreativitas Anak Berbakat. Jakarta: PT Rineka Cipta

Nurhadi. 2002. Pendekatan Kontekstual. Jakarta: Departemen Pendidikan

Panjaitan. 2013. Pembelajaran Matematika Beraliran Humanistik Pada pendekatan Kontekstual

Sanjaya, Wina. 2011. Strategi Pembelajaran Berorientasi Standar Proses Pendidikan Jakarta: Predana Media.

Shoimin, Aris. 2018. Model Pembelajaran Inovatif Yogyakarta: Ar-Ruzz Media

Trianto. 2011. Mendesain Model Pembelajaran Inovatif -Progresif. Jakarta:Kencana Prenada Media Group 